\title{
Tolerance Management in Oikumene Senior High School As Strengthening Religious Moderation
}

\author{
Asnandar Abubakar ${ }^{1}$, Rosdiana Muas ${ }^{2}$, Husnul Fahimah Ilyas ${ }^{3}$, Amiruddin $^{4}$ \\ \{asnandar2.aja@gmail.com ${ }^{1}$,rosdianalitbang03@gmail.com², husnullitbang@gmail.com³, \\ amiruddinlaterru@gmail.com $\left.{ }^{4}\right\}$
}

Research \& development and Training Ministry of Religion Indonesian ${ }^{1}$, Institute of Islamic Religion State Sorong ${ }^{2}$, Research \& development and Training Ministry of Religion Indonesian ${ }^{3}$, Research \& development and Training Ministry of Religion Indonesian ${ }^{4}$

\begin{abstract}
The research objective was to see the management of tolerance in Oikumene Senior High School (SMA Oikumene) as strengthening religious moderation in terms of strengthening the experience and understanding of religion for the school community. This research is a qualitative research to describe the phenomenon of research findings with the tendency of inductive analysis with a descriptive approach to data collection which uses observation, interviews, and documentation. Data analysis was carried out systematically which included organizing data, categorizing data, and interpreting it according to the meaning and forms of reporting then presented descriptively qualitatively. Strengthening religious tolerance of SMA Oikumene Kendari through respect for religious holidays and commemorating them, programs of faith and piety activities, equality of ethnicity, religion, and culture, equality of duties and functions of teachers from various religions, strengthening of egalitarian religions, social service activities, and embodiment of love as the basis for providing education. Strengthening tolerance, namely tolerance in the context of religion, tolerance in the social context, and tolerance in a cultural context. Building tolerance in SMA Oikumene is a manifestation of religious, social and individual values.
\end{abstract}

Keywords: tolerance management, religion, religious moderation

\section{Introduction}

The appreciation of religious values in educational units is not only emphasized on students but also on religion teachers. Religious values elevate human dignity in seeing social plurality, cultural diversity, and differences in ethnicity, race, group. Religious values provide a spirit of life and the ability for humans to accept differences to be harmonious and peaceful between others. Accepting differences is one meaning of tolerance. Tolerance is the middle way in fostering harmony and giving meaning to the importance of diversity in society or in educational units.

Tolerance management in educational units is not only aimed at students but also at teachers. Teachers have a big responsibility for strengthening tolerance because they have a crucial task of transforming and opening the horizons of learners' knowledge of the meaning of tolerance. A teacher's religious understanding will color the meaning of tolerance given to students. Exclusive religious understanding can backfire for fostering harmony among students.

One medium for strengthening tolerance is through educational units or schools by managing tolerance in accordance with the corridors of religion and culture of the nation and 
state. Management of tolerance in schools is an urgent thing to do. There are still many students who do not understand the meaning of tolerance. The Ministry of Education's research results show the seeds of intolerance in the school environment. There are still students who tend to reject the Chair of the Student Council with a different religion. The Government tries to suppress this intolerant practice.

The results of these studies are certainly very surprising for all of us. Why does this happen? There are several aspects that can be the cause, first, of course, the weak tolerance education implemented in schools. Second, the religious education provided to students tends to be a doctrine and symbolic meaning of religion, giving less space to the substance of religious values itself in a broader and universal perspective.

The intolerant attitude of students can become embers in the husk which at times can lead to acts of radicalism in the sense of religious and cultural vandalism. Radical action among students is not impossible to do. The results of survey research conducted by the Jakarta Institute for Islamic Studies and Peace (LaKIP) in 2010 were surprising, as many as $48.9 \%$ of students in Jabodetabek expressed their approval of radical action (Rosyid, Sholikin, and Moh. Sa'diyin, 2018). Likewise, the results of research conducted by the Makassar Research and Development Center for Religion (BLAM) on several students in Eastern Indonesia in 2016 showed that around $10 \%$ of students had potentially radical attitudes (BLAM Research Report, 2016).

Therefore, the diversity that we have must be managed properly and become the basis for unifying the nation, because if it is neglected, the impact will be very dangerous, it can damage the joints of the life of the nation and state. If the social capital of diversity is not managed properly, it will be counterproductive in an effort to create a life of peace, harmony and tolerance (Syarifuddin, Masyhuri, and Suud, 2019).

The management of diversity and diversity of society should not lead to discrimination, because of course it will disturb religious tolerance. All must receive the same treatment. In strengthening national life, Indonesian citizens do not recognize discrimination, live together with tolerance, avoid feelings of suspicion between one another, and differences between ethnic groups are not something that separates them from daily interactions (Tilaar, 2007: 39).

Discrimination against respectful treatment for differences in religion, race, ethnicity and class is the seed for the emergence of radicalism and intolerance. Intolerant attitudes can stimulate horizontal conflicts in society or in educational units in particular. Conflict arises from the fact that there are differences in terms of both physical (body), emotional, cultural, needs, interests, and behavior patterns between individuals or groups in society (Ahmadi, 2007: 282).

The pattern of managing tolerance in schools must be seriously thought about and implemented to prevent discrimination that can lead to conflicts between students. Especially in the current era, students easily receive information on both cultural egos and exclusivism of certain groups. In today's era of globalization, intercultural meetings are a serious threat to students, by which students need to be made aware of diverse knowledge in order to have broad competence in global knowledge (Mahfud, 2013: 218).

One of the strengthening of tolerance is strengthening religious education learning. Religious learning is given according to its portion, meaning that it pays attention to psychology and the level of thinking power of students. Do not let the lessons given be too deep so that it is difficult for students to digest. Learning must be relaxed and fun accompanied by innovation and creative learning media. Religious education plays a very important role in preventing the radicalism of students. PAI must play a role in reducing 
radicalism in students' thinking and understanding from the start before it develops in a negative direction in the form of radicalism to various spheres of life in society. (Bahruddin, Rosyadi, and Edy, 2018).

Therefore, students should not consider religious education boring. As stated by Hamdini, that according to the students, the learning atmosphere in the classroom, especially in PAI and Character subjects was less fun and motivating because the learning strategies used were less varied, and it seemed that they had to study on their own with the material in the book, unlike in another lesson (Hamdini, 2017).

Indonesia in the span of 10 years indicates symptoms of intolerance, radicalism and terrorism. Terrorism, attacks and expulsion of minority groups, banning activities, and burning books are some forms of intolerance and radicalism. Indonesia still has the potential for intolerance and radicalism, some of which have occurred even though only in a few regions, most of which are not impossible to surface massively in the future, if not handled seriously. (Rosyid, Sholikin, and Moh. Sa'diyin, 2018)

The radicalism movement, especially religious radicalism, is a threat not only to multiculturalism but also to the Unitary State of the Republic of Indonesia (NKRI). In connection with this danger, President Susilo Bambang Yudoyono (SBY) in the Musrenbangnas meeting on 28 April 2011 was attended by all Ministers of United Indonesia Cabinet II, Governors, Regents / Mayors throughout Indonesia emphasized that "Terrorism and Radicalism / Violence are serious threats". According to President SBY, the Indonesian nation is currently facing serious threats related to terrorism, horizontal violence and radicalism which continue to occur in a number of places, if not addressed seriously, this condition could have an impact on the harmony of the nation's life in the future (Syafei, 2018).

Good management of tolerance can prevent the emergence of radicalism and reinforce religious moderation. Religious moderation gives a noble meaning to the respect of existing religions. Religious moderation can be used as a middle way for each person to accept differences. Religious moderation must be understood in a concrete and universal way, not only between religions but also within religions. As in Islam, the complexities faced by Islam today require us to maintain a moderate (tawassuth) and tolerant (tasâmuh) understanding. Mistakes in interpreting Islamic teachings so that actual actions and actions tend to conflict with Islamic teachings itself. This is where one of the roles of moderation (wasathiyyah) to penetrate this understanding in diversity (Abdillah, 2015).

In educational units, moderation is very important to be strengthened to provide the meaning of justice to the different religious views of students. Moderation requires balanced and fair attitudes and actions (justice). Without balance and justice, calls for religious moderation are ineffective. Moderate means that each of them must not be extreme on each side of his perspective, both of them must approach and pick up points of commonality rather than insisting on 'digging' the intersection of differences (Saefuddin, 2019).

Religious moderation is very important as a frame in managing religious life in plural and multicultural Indonesian society. The word Moderation of Religion does not mean a single interpretation of what applies in the public sphere, but only contextualizes the interpretation of Religious Moderation within the scope of the main duties and functions of the Ministry of Religion as the guardian of community togetherness through education and religion (Saefuddin, 2019).

Based on the above views, it is necessary to conduct research on the management of tolerance in public schools as a strengthening of religious moderation. The formulation of the research problem is inseparable from the narrative descriptions of the background, by him it is 
defined as follows, namely How to manage tolerance in public schools as strengthening religious moderation.

The research objective is to see the management of tolerance in public schools as a strengthening of religious moderation. Meanwhile, the use of research is that it can be used as a reference material for managers of educational institutions as a strengthening of experience and understanding of religion. For the government, it can be used as a policy material in making or developing regulations related to religious tolerance and moderation.

\subsection{Literature Review}

\subsubsection{Tolerance}

In Chaplin (2009: 512) it is stated that tolerance is an attitude of liberalism, or does not want to interfere and does not interfere with the behavior and beliefs of others. In Webster's World Dictionary of American Language, (Gularnic, 1959) it is stated that etymologically the word tolerance comes from Latin, namely tolerare which has the meaning of holding, bearing, fixing, letting go, and steadfast. Whereas in English, the word tolerance is interpreted as tolerance which means the attitude of allowing, acknowledging, and respecting the beliefs of others without requiring approval.

Tolerance which comes from the word Tolerare means patiently letting something go. So the broad understanding of tolerance is an attitude or human behavior that does not deviate from the rules, where someone appreciates or respects every action that other people do. Tolerance can also be said to be a term in the context of socio-culture and religion which means attitudes and actions that prohibit discrimination against different groups or cannot be accepted by the majority in a society.

In the Big Indonesian Dictionary, it is explained that tolerance is a tolerant trait or attitude, that is, it has the character or attitude of being tolerant (honoring, allowing, allowing) the position (view, view, belief, habits, behavior that are different or contrary to one's own stand, for example religious tolerance (ideology, race, and so on).

Sullivan, Pierson, and Marcus (in Mujani, 2007: 162), define theory as a willingness to "put up with" those things one rejects or opposes, namely the willingness to appreciate, accept, or respect everything that someone rejects or opposes.

In Arabic, tolerance is interpreted as tasamuh, which means allowing something to allow and facilitate each other. From the word tasamuh, it is intended that those with different opinions should be able to give each other a place for their opinions. Each opinion has the right to develop his opinion and not offend one another.

Tolerance is acceptance, respect, and appreciation for differences, giving freedom and equality to a group or community carrying out social and religious attitudes while still paying attention to social norms and religious values (Ismail, 2012), (Widiyanto, 2017), (Fuad, 2018), (Yasa, 2019)

The concept of tolerance is not equated with cultural and ethnic diversity, but emphasizes cultural diversity and equality. In learning in the school environment it is necessary to provide insight or introduce diversity and tolerance to multiculturalism. (Widiyanto, 2017).

It is necessary to introduce diversity and tolerance in society. Diversity needs to be supported by tolerance to create peace in society. (Suliantoro and Runggandini, 2018), (Hartoyo, 2010), (Affandi, 2012), (Triguna, 2019), (Khaerurrozikin 2015). 


\subsubsection{Moderation}

Moderation is an activity to conduct a review so as not to save from the applicable rules that have been set. Linguistically speaking, the word 'moderation' comes from the Latin moderâtio, which means moderation (neither strength nor deficiency). The word also means "self-control" (from being overly strong and lacking). The Big Indonesian Dictionary (KBBI) provides two definitions of the word 'moderation', namely: 1. reduction of violence, and 2. avoidance of extremes. The word moderation contains two meanings, namely, guiding / regulating / mediating and reducing violence and avoiding extremes. Both meanings are similar and equally applicable, carrying out the function of control. Moderating means controlling something so that it doesn't go too far, pulling things that are outrageous so that they are on the right track, and fitting things to achieve balance (Saifuddin, 2019).

In the context of the life of a plural and multicultural society such as Indonesia, moderation must be understood as a shared commitment to maintain a complete balance, where every member of society, regardless of ethnicity, ethnicity, culture, religion, and political choices must be willing to listen to one another, and learn from each other to practice the ability to manage and overcome the differences between them. Obviously, moderation is closely related to tolerance (Saifuddin, 2019).

Moderation can be interpreted as a middle way, and it has the same meaning as alwashatiyyah which comes from the word wasath which means fair, good, middle, and balanced (tawazun). Therefore, moderation in Islam can be seen from; first, there is a right to freedom which must always be balanced with obligations. Second, there is a balance between worldly and ukhrawi, as well as material and spiritual life so that the civilization and progress achieved by Muslims is not pseudo and mirage, but true and true to what is expected, namely realizing goodness in the world and in the hereafter. (Afifon, 2015).

Yusuf al-Qaradhawi, a scholar and moderate Ikhwan figure suggests the meaning of moderation, including: (1) comprehensive understanding of Islam, (2) balance between shari'ah provisions and changing times, (3) support for peace and respect for values humanity, (4) recognition of religious, cultural and political plurality, and (5) recognition of minority rights (Abdillah, 2015).

Mohammad Hashim Kamali in his book, The Middle Path of Moderation in Islam (Oxford University Press, 2015), emphasizes that moderate, which in Arabic means wasathiyah, cannot be separated from two other keywords, namely balanced (balance) and fair ( justice). Moderate does not mean that we compromise with the main principles of ushuliyah) religious teachings that we believe in order to be tolerant towards people of other religions, but moderate means confidence, right balancing, and justice. Without balance and justice, calls for religious moderation will be ineffective. Thus, moderate means that each of them must not be extreme in each side of his view. Both of them must approach and find common ground (Fathurahman, 2018).

\section{Metodology}

This research is a qualitative research that describes descriptive data to describe the phenomenon of research findings with a tendency to analysis inductively. This study uses a descriptive approach that is structured in such a way as to describe or explain activities or events related to the data obtained. 
This research makes SMA Oikumene a target school located in Kendari City, Southeast Sulawesi Province. SMA Oikumene is a school that is under the auspices of the Christian Religious Education Foundation.

Data collection techniques used in this study were observation, interviews, and documentation. In qualitative research, data collection is carried out in natural settings (natural conditions), primary data sources, and data collection techniques are mainly participant observation, in-depth interviews and documentation.

Data analysis was carried out based on the form and nature of the data collected. Data analysis was carried out systematically which included organizing data, categorizing data, and interpreting it according to the meaning and forms of reporting then presented descriptively qualitatively.

\section{Result and Findings \\ 3.1. Overview of Oikumene High School}

SMA Oikumene was founded in 1981 on an area of 10,000m2, under the auspices of the Christian Education Foundation located on Jalan Taridala Number 24, Mandonga District, Kendari City. This foundation was formed in 1965 and began implementing educational services in 1972 at the kindergarten and elementary school levels. SMA Oikumene was the forerunner to the formation of SMA Negeri 1 Kendari, because at that time Christian schools were the pioneers of the existence of schools which were a legacy of Dutch zanding education. Christian schools are Dutch assets that were handed over to the Church after the colonial period ended.

The number of students of SMA Oikumene is 82 students, consisting of 44 students who are Muslim and 38 students who are Christian. The number of teachers was 21 people consisting of 11 PNS teachers and 10 non PNS teachers. The potential in the school environment that is expected to support the school program, including: the location of the school is very strategic in the city center, most of the teachers live in the Oikumene school complex (housing), have supporting facilities such as a science laboratory, library, multipurpose hall, canteen students, and sports fields. .

SMA Oikumene has a vision: Achieving in Quality, Polite in Behavior, Excellence in Culture. To realize this vision, the school sets a mission, namely; (1) increasing teacher creativity resources in implementing education, teaching and training, (2) encouraging students to be more innovative in character building, academic mastery, and life skills, (3) encouraging students to live healthy and appreciate art both through intra and extracurricular activities, (4) inculcating the excellence of the school effectively especially to all school members and society in general, (5) increasing faith and piety in God Almighty, (6) instilling noble character, love for the motherland, and manners in accordance with national culture (especially D3S: Discipline, Smile, Greet and Courtesy), (7) encourage and shape each student to understand / master national / international languages, and (8) develop an entrepreneurial culture among students.

The goals of the Oikumene High School are; (1) building character of students who are strong, creative, intelligent, independent, productive and able to take advantage of existing opportunities or resources, (2) provide services of knowledge and skills facilities to be able to continue to higher education levels, (3) empower libraries, educational facilities laboratories and expanding networks and cooperation with the business world, industry, the community to obtain life knowledge and skills, (4) improving national and or international communication 
and language skills, (5) establishing strong and tolerant religious practitioners, having a national personality, loving the country and having noble character through the development of the school climate, and (6) improving education services by involving all school members, school committees, inter-school networks, Dinas and other components in school management.

\subsection{Strengthening Tolerance of Oikumene High School}

\subsubsection{Respect for Religious Holidays}

The patterns of managing tolerance at SMA Oikumene Kendari include carrying out activities to commemorate religious holidays, both Islam, Christianity, and Hinduism. The commemoration of the birthday of the Prophet Muhammmad Saw is scheduled by the principal every year by forming an implementation committee and a schedule and agenda of activities. The committee involves teachers, not only teachers who are Muslim but also teachers who are Christian and Hindu, even Christian teachers who organize and manage many activities, as stated by Mrs. Nuryati Sagune (Christian teacher) that:

Celebrating the birthday of the Prophet Muhammad at this school, we guide students to make male (a kind of place for offerings which usually contains sticky rice and eggs as a characteristic decorated with various ornaments to make it look attractive). This male is competed between classes (even between schools). Our venue is also set up. Islamic teacher friends are only asked to provide or invite lecturers.

The implementation of the Prophet's Birthday, apart from involving teachers, also involved students from various religions at SMA Oikumene, even Christian students who were more enthusiastic about preparing the event. Likewise, when the religious lecture took place, both Christian and Hindu teachers and students sat together to listen to the lecture.

Ms. Nuryati Sagune is in charge of spiritual activities at Oikumene High School. All spiritual activities both carried out by the school internal and external schools are under the coordination of Ms. Nurhayati, so that she is very attentive and active in participating in religious activities both Christianity, Islam and Hinduism.

The same thing about the celebration of religious holidays at SMA Oikumene was also conveyed by the principal of SMA Oikumene, Mrs. Iriani Rustiah: In the celebration of Islamic holidays, all teachers and students are involved in the success of the event, and vice versa if other religious celebrations such as Christianity, teachers and students from religions other than Christian are also involved. In this celebration, parents of students were involved and invited to attend, although not all were able to attend, the involvement of parents had shown a relationship of cooperation with teachers and students. Apart from parents, school alumni are also involved. Celebrating the Prophet's birthday all students are involved in activities, such as making baskets or men, carrying eggs, and decorating baskets.

There are several important aspects that are obtained at the celebration of religious holidays, especially regarding the development and strengthening of student tolerance, including: respecting other people's religions and beliefs, appreciating and practicing religion, fostering unity and unity in society, as a nation. and a state, fostering a sense of brotherhood among fellow religions, preventing disputes and enmity in the name of religion, creating conditions and an atmosphere that is safe, peaceful, and friendly, fosters mutual help and mutual cooperation, fosters behavior of mutual sharing among others, prevents the emergence of behavior anarchists and religious extremism, and mutual respect in terms of differences in religion, ethnicity, taste, and culture. 


\subsubsection{Faith and Piety Activity Program}

Another strengthening of tolerance is the implementation of programs of faith and piety activities every Friday. Christian students are gathered in one class to carry out worship such as prayer 'together (liturgy). Students who are Muslim are given permission to worship outside of school. As stated by Mrs. Nuryati that SMA Oikumene carries out a program of faith and piety activities:

IMTAQ (faith and piety) activities are carried out every Friday morning, for Muslim students to perform Friday prayers at the mosque (there are students who are responsible for this worship activity). For Christian students who carry out services that are held every morning and afternoon, Catholic students join in with other Christian students by praying together, reading the word, and singing (Charismatic and Pentecostal students).

This was also conveyed by the Principal of the School, Ibu Iriani, that one of the programs to strengthen tolerance and harmony in the Oikumene High School environment is the strengthening of faith and piety. This activity is carried out every day, namely in the morning before learning begins and in the afternoon during study breaks. In the morning students are encouraged to pray according to the teachings of their respective religions, and during the daytime Muslim students carry out Dhuhr prayers and Christian students carry out worship (pray) at a specified place. The implementation of the students' worship is accompanied and controlled by the teacher who has received responsibility from the school principal.

Friday prayers and Dhuhr prayers for Muslim students are mandatory. The implementation of this worship is controlled by Pak Akbar (Islamic Religious Education Teacher). Students are given leeway during the day to worship. (interview with Mrs. Iriani).

Faith and piety activities carried out at Oikumene High School are intended to provide practice and appreciation of the teachings or beliefs of religion by interpreting the religious values contained therein through sincere and sincere worship to God Almighty. Through worship, students can absorb the value of love and peace and practice it in their daily lives so that they can avoid arrogance, arrogance, and hate.

Another meaning of this activity of faith and piety is to provide habituation and raise awareness for students to carry out worship, so that this routine is embedded in the students 'soul and body and is expected to have a good impact on students' morale and behavior. When this habit is embedded in students, laziness is reduced and prevented wherever students are at school or at home.

Another Faith and Faith activity is the study of the Bible for Christian students, namely studying and interpreting Christian teachings in the Bible. Students who are Muslim carry out Islamic boarding schools, namely the deepening of Islam together at a certain time and at the same time carrying out worship in congregation. This activity aims in addition to increasing students' religious understanding, also to provide reinforcement to students, especially in entering adolescence (self-introduction).

\subsubsection{Equality of Tribe, Religion, Culture in Admission of New Students}

The admission of new students at SMA Oikumene is carried out at the beginning of the new academic year (early semester) with several requirements as generally applicable to other high schools based on government regulations. Even though SMA Oikumene is under the auspices of a Christian education foundation, admission of new students is not required to 
adhere to Christianity, all religions can be accepted because there is no special curriculum for Christian religious education.

The diversity of cultures, ethnicities, races, and religions at SMA Oikumene provides opportunities for students to know closely the understanding of each other's teachings within the scope of social, cultural and religious tolerance. This condition can parse the exclusivity of certain religions so that they do not feel superior alone or arbitrarily against a minority, so that disparities in the perspective of treatment, service and attention can be minimized.

The school management's expectations of strengthening the harmony of affiliated religious communities in the admission of new students. The new admissions committee involves teachers and students of all religions. Teachers who are Muslim and Hindu are given roles such as teachers of various Christians, as well as students of class XI and XII of all religions are given the task of introducing the school environment to new students. This equality of roles will avoid discrimination and intimidation of treatment of certain religions so that harmony and tolerance in religious diversity can be created in a harmonious atmosphere.

The admission of new students also does not limit religious identities or symbols, such as the use of the headscarf for Muslim students to be given leniency or flexibility as long as it is within tolerance limits such as not covering their faces or not wearing a headscarf that is too big, the use of this hijab is not obligatory for Muslim students who haven't worn it.

\subsubsection{Equality of Duties and Functions of Teachers From Various Religions}

The reality of educators and education personnel at SMA Oikumene is not only dominated by Christian teachers, but also Muslim and Hindu teachers. The roles given by school leaders are not differentiated as long as they can carry out their duties and functions optimally with the principle of responsibility. The duties and functions of the teacher are adjusted to their competence. One of the teacher's duties is to teach in accordance with the subject being taught. The fulfillment of teaching hours for teachers is met based on standard needs and positions, and is arranged based on the hours of instruction in the school curriculum.

In addition to fulfilling and equalizing lesson hours, the duties and roles of teachers in other activities are also given the same, such as the committee for admitting new students or committees for other school activities, duties as homeroom teachers, duties as extracurricular coaches, and equal distribution of school leadership structures. (vice principal). Equitable distribution of teacher duties and equal treatment of teachers from various religions, make teachers feel they have and share responsibility for school management without thinking that this school is a school under the auspices of Christianity.

The distribution of roles equally for all teachers of various religions by the principal shows an attitude of avoiding feudalism of the leadership authority. The principal does not give power or role only to certain groups or religions. This action or attitude reflects respect for the values of tolerance and reinforcement of religious harmony. The importance of strengthening tolerance in the school environment is an acknowledgment of the diversity of religious communities.

\subsubsection{Strengthening Egalitarian Religion Adherents}

Egalitarianism of religious adherents is the same recognition and treatment of religious adherents without differentiating between position, ethnicity, taste, or culture for both teachers and students. All religious believers at SMA Oikumene are given the same 
rights and opportunities to carry out their religious orders and prohibitions, worship according to religious demands, and carry out religious ceremonies. The teacher does not prohibit students from carrying out worship at certain times, so the school leadership does not prevent the teacher from carrying out worship at certain hours, the important thing is that teaching and learning activities can run according to a predetermined schedule.

This same recognition and treatment builds social harmony in the perspective of religious tolerance. Social harmonization will create peace and a conducive atmosphere for religious believers within the scope of the school. The existence of peace in the school environment makes school activities run optimally, efficiently and effectively. All school members feel comfortable and calm because there is no disturbance or friction due to differences in religion or belief. With comfort, the spirit of learning is maintained so that individual and school achievements can be realized in accordance with the targets that have been previously set.

Respect for religious followers in schools is a social capital when interacting in the community. Rational attitudes and behavior have implications for morals and morals in accordance with culture, religion and other social values. This social capital affirms high optimism for the creation of harmony in cultural and religious diversity. With social capital, students can act as agents of change in the forefront of socializing the importance of respect and respect for religious differences.

\subsubsection{Social service}

Social service is one of the activities that has been scheduled in the school program. These activities include cleaning the environment around the school (outside the school). Activities carried out by picking up scattered trash, cleaning waterways. This activity is very important to do to create a clean environment and prevent flooding when the rainy season arrives. All students and teachers were involved by dividing their respective assignments. Some are in charge of cleaning up garbage, some are collecting and some are transporting garbage to a temporary dumpsite. Activities coordinated by the teacher and a student representative.

Other social service activities include visiting and cleaning religious and historical places. This activity is intended to get to know the places of worship of various religions more closely, to broaden the horizons of knowledge about the existence of religions and their spread. All students were involved even though the places of worship visited were different from their religions. For example, when visiting the Church, students who have faiths other than Christianity are involved. Likewise, when visiting the mosque, students who are not Muslim are also involved.

This activity is highly appreciated by the surrounding community, the community gives the view that the embodiment of the values of tolerance in SMA Oikumene has been running in accordance with social, cultural and religious norms. Expectations for strengthening tolerance in schools are highly expected by the surrounding community, because it will have a good impact on religious harmony and social harmony in society, and will transmit the seeds of peace that can prevent social friction among adolescents around the school. Young people or teenagers around the school by themselves also participate in not only maintaining cleanliness, but also maintaining order and safety in the surrounding environment.

This social service activity is a manifestation of mutual cooperation which is the cultural heritage of our ancestors. Gotong royong is the basis of our nation's philosophy of 
cooperation which is based on kinship and brotherhood. Work together to achieve the desired results. With mutual cooperation, it will strengthen the bonds of brotherhood, mutual understanding, mutual respect, and helping one another. This is where the meaning of tolerance is developed and understood by all elements of society.

\subsubsection{Love As the Foundation for Providing Education}

The implementation of education at SMA Oikumene takes place in accordance with the school activity program that has been set at the beginning of the school year. The school program consists of learning activities according to the agreed curriculum (curriculum 2013 / K13) and other activities to support and support learning. Activities that take place at school are supported by school rules and regulations. Rules are enforced to enforce discipline in all components of the school so that teaching and learning activities can take place efficiently and effectively, and maintain student morale and behavior so as not to come out and order cultural and religious norms. Even though the rules are strictly enforced, the school leadership still runs the rules based on love. Love means being patient, generous, not being arrogant, helping wholeheartedly, considering relationships with others as brothers and friends, respecting others despite different religions and beliefs.

The implementation of education based on this love, is in accordance with the name of the school, namely ecumenical or ecumenical, which means that the contents of the teachings and adherents are respected because in Christianity there are elements of love, and adherents also understand that in the teachings of other religions there are elements of mutual respect and respect. respect among others. Respect and respect for the teachings of other religions is a manifestation of the development and strengthening of the values of tolerance and harmony among religious communities.

With love, it will create a harmonious relationship in the school environment, both among students, among teachers, or between teachers and students, and create a conducive atmosphere so that learning activities can run comfortably without suspicion and exclusivism treatment due to religious differences.

The manifestation of love is fear of God. Fear of a creator is an infiltration of the sincerity of a people into the soul to acknowledge sincerely as a servant, and to believe wholeheartedly that this universe is governed by the Creator of God Almighty. SMA Oikumene motto "Fear of God is the Beginning of Knowledge", meaning that knowledge must be based on belief and religion, so that it can benefit mankind and the natural environment.

\section{Conclusion}

Strengthening tolerance at SMA Oikumene Kendari is implemented through various activities including respect for religious holidays and commemorating them, programs of faith and piety activities, ethnic, religious and cultural equality in admitting new students, equality of duties and functions of teachers from various religions, egalitarian strengthening adherents of religion, social service activities, and embodiments of love as the basis for providing education.

Strengthening tolerance in schools is seen from three contexts, namely tolerance in the religious context, tolerance in the social context, and tolerance in the cultural context. Strengthening Tolerance in the context of religion respecting and respecting the teachings and 
religious beliefs of others, understanding and participating in the commemoration of other people's religious holidays, and maintaining and caring for the worship activities of others.

Cultivating empathy by building tolerance is a manifestation of the social values of society that guide individuals to respect their rights and obligations in their relationships because humans are both individual and social creatures, meaning that humans must be able to meet their needs both independently and with the support and assistance of others. Individuals must be able to interact with others and build good communication. In this interaction process, individuals are required to understand and understand differences from one another, so that the ripples of disputes due to differences in ethnicity, race and religion can be minimized.

\section{Acknowledgement}

Thank you very much, the authors thank all informants in this study, especially to the Principal of SMA Oikumene Dra. Iriani Rustiah and all Educators and Education staff, as well as students and students who have accepted researchers to carry out this research. To the Head of the Madrasah Education Sector at the Regional Office of the Ministry of Religion of Southeast Sulawesi Province and staff who have assisted researchers in providing related data. To the Head of the Makassar Research and Development Center for Religion who has assigned researchers to carry out this research. And to fellow researchers in the field of Religious and Religious Education who have provided criticism, suggestions and input as an effort to improve this research.

\section{References}

[1] Abdillah, Masykuri. 2015. Meneguhkan Moderasi Beragama. Harian Kompas (09 Februari 2015). http://graduate.uinjkt.ac.id/?p=17325. Diunduh tanggal 28-03-2019.

[2] Affandi, Nurkholik. 2012. "Harmoni Dalam Keragaman (Sebuah Analisis Tentang Konstruksi Perdamaian Antar Umat Beragama).” Jurnal Komunikasi Dan Sosial Keagamaan 15 (01): 71-84.

[3] Afifon, Irfan. 2015. Arti Moderasi Dalam Islam. http://www.halhalal.com/arti- moderasi-dalam islam/. Diakses pada 27-02-2019.

[4] Ahmadi, Abu. 2007. Psikologi Sosial. Jakarta. Rineka Cipta.

[5] Aulia, Rahmah, and Iyus Akhmad Haris. 2017. "PERSEPSI SISWA TERHADAP PENERAPAN

SISTEM FULL DAY SCHOOL Di MTS MARDHATILLAH SINGARAJA TAHUN AJARAN

2017/2018." Ejournal Jurusan Pendidikan Ekonomi 10 (2).

[6] Bahruddin, E, Abdu Rahmat Rosyadi, and Edy. 2018. "Persepsi Siswa Madrasah Tsanawiyah Terhadap Pendidikan Multikultural Keagamaan Dalam Penanggulangan Radikalisme Secara Dini.” Edukasi Islami: Jurnal Pendidikan Islam 07 (02): 179-94.

[7] Abdillah, Masykuri. 2015. Meneguhkan Moderasi Beragama. Harian Kompas (09 Februari 2015). http://graduate.uinjkt.ac.id/?p=17325. Diunduh tanggal 28-03-2019.

[8] Affandi, Nurkholik. 2012. "Harmoni Dalam Keragaman (Sebuah Analisis Tentang Konstruksi

Perdamaian Antar Umat Beragama).” Jurnal Komunikasi Dan Sosial Keagamaan 15 (01): 71-84.

[9] Afifon, Irfan. 2015. Arti Moderasi Dalam Islam. http://www.halhalal.com/arti- moderasi

dalam-islam/. Diakses pada 27-02-2019.

[10] Ahmadi, Abu. 2007. Psikologi Sosial. Jakarta. Rineka Cipta.

[11] Aulia, Rahmah, and Iyus Akhmad Haris. 2017. "PERSEPSI SISWA TERHADAP

PENERAPAN SISTEM FULL DAY SCHOOL Di MTs MARDHATILLAH SINGARAJA

TAHUN AJARAN 2017/2018." Ejournal Jurusan Pendidikan Ekonomi 10 (2).

[12] Bahruddin, E, Abdu Rahmat Rosyadi, and Edy. 2018. "Persepsi Siswa Madrasah 
Tsanawiyah Terhadap Pendidikan Multikultural Keagamaan Dalam Penanggulangan Radikalisme Secara Dini.” Edukasi Islami: Jurnal Pendidikan Islam 07 (02): 179-94.

[13] Chaplin, James P. 2009. Kamus Lengkap Psikologi. Rajawali Pers. Jakarta.

[14] Fathurahman, Oman. 2018. Opini Kompas (30 Mei 2019) 6.

http://fah.uinjkt.ac.id/tentang-moderasi-agama/. Diakses pada tanggal 28-03-2019.

[15] Fuad, A Jauhar. 2018. "PEMBELAJARAN TOLERANSI Upaya Guru Pendidikan Agama Islam Dalam Menangkal Paham Radikal Di Sekolah.” In Annual Conference for Muslim Scholars, 9:561-71.

[16] Gularnic, David G. 1959. Webster's World Dictionary of American Language. New York: The World Publishing Com $\neg$ pa $\neg$ ny.

[17] Hamdini, Izmi Rafi, and Fitri Aulia. 2017. "Ketidakseimbangan Bakat Dan Prestasi Siswa Pada Mata Pelajaran PAI Dan Budi Pekerti Di SMP Negeri 5 Yogyakarta.” Jurnal Konseling Pendidikan 1 (1): 57-73.

[18] Hartoyo, Agung. 2010. "Menggugah Kesadaran Nasional Mempengaruhi Kebhinekaan Indonesia." Jurnal Pendidikan Sosiiologi Dan Humaniora 01 (02): 132-47.

[19] Ismail, Roni. 2012. “Konsep Toleransi Dalam Psikologi Agama.” Jurnal Religi VIII (01): $1-12$.

[20] Khaerurrozikin, Ahmad. 2015. "Problem Sosiologis Pluralisme Agama Di Indonesia." Jurnal Kalimah 13 (01): 85-102.

[21] Rosyid, Halimur, Ahmad Sholikin, and Moh. Sa'diyin. 2018. "Intoleransi, Radikalisme, Dan Teroris Di Lamongan.” Jurnal Polinter Prodi Ilmu Politik Fisip Uta'1945 4 (1): 1-20.

[22] Suliantoro, Bernadus Wibowo, and Caritas Woro Murdiati Runggandini. 2018. "Konsep Keadilan Sosial Dalam Kebhinekaan Menurut Pemikiran Karen J . Warren.” Respons 23 (01): 39-58.

[23] Syafei, Imam. 2018. "Pengaruh Tingkat Pengetahuan Agama Terhadap Persepsi Mahasiswa Pada Gerakan Radikalisme Berbasis Agama (Studi Pada Mahasiswa Uin Raden Intan Lampung).” Al-Tadzkiyyah: Jurnal Pendidikan Islam 9 (I): 61-79.

[25] Syarifuddin, Masyhuri, and Suud. 2019. "Urgensi Pendidikan Multikultural Untuk Mencegah Faham Radikalisme Pada Siswa SMA Dan MA Di Kecamatan Dompu.” Jurnal Pendidikan Dan Pengambdian Masyarakat 2 (1): 36-42.

[26] Triguna, I.B.G. Yudha. 2019. "Kebhinekaan Bangsa Indonesia: Urgensi Dan Relevansinya Dalam Era Revolusi 4.0.” Dharmasmrti: Jurnal Ilmu Agama Dan Kebudayaan 10 (02): 46-52.

[27] Widiyanto, Delfiyan. 2017. "Pembelajaran Toleransi Dan Keragaman Dalam Pendidikan Pancasila Dan Kewarganegaraan Di Sekolah Dasar.” In Prosiding Konferensi Nasional Kewarganegaraan III, Universitas Ahmad Dahlan Yogyakarta, 109-15.

28] Yasa, I Wayan Catra. 2019. "DETERMINASI KONFLIK, TOLERANSI TERHADAP KERUKUNAN ANTAR UMAT BERAGAMA DI KOTA BATAM.” Jurnal Menara Ilmu XIII (5): 49-58. 